\title{
Akut Apandisit Hastalarında Ghrelin Hormon Düzeyi Bakılması ve Ghrelin Hormon Düzeyinin C-Reaktif Protein ve Beyaz Kan Hücre Düzeyleri ile Karşılaştırılması
}

\section{Investigation of Ghrelin Hormone Level in Acute Appendicitis Patients and Comparison of Ghrelin Hormone Level with C-Reactive Protein and White Blood Cell Levels}

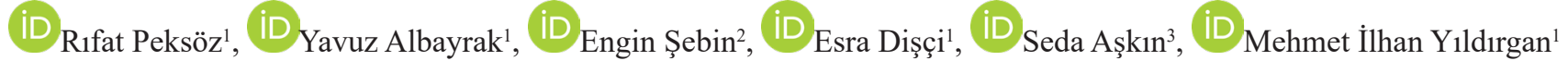

${ }^{1}$ Atatürk Üniversitesi Tıp Fakültesi Genel Cerrahi Anabilim Dalı, Erzurum-Türkiye

${ }^{2}$ Erzurum Bölge Eğitim Araştırma Hastanesi Biyokimya Birimi, Türkiye

${ }^{3}$ Atatürk Üniversitesi Tıp Fakültesi Biyokimya Anabilim Dalı, Erzurum

Öz

Amaç: Bu çalışmada akut apandisit hastalarında ghrelin hormonunun tanısal değerininin incelenmesi ve white blood cell (WBC), c-reaktif protein (CRP) gibi rutin kullanılan laboratuvar testleriyle korelasyonunun değerlendirilmesi amaçlanmıştır.

Yöntem: Ekim 2018 ile Aralık 2018 tarihleri arasında akut apandisit ön tanısı ile ameliyat edilen 16-80 yaş arası hastalar prospektif olarak incelendi. Preoperatif dönemde hastalardan hemogram ve CRP ile birlikte ghrelin hormon düzeyi ölçümü için kan alındı. Hastalar 3 gruba ayrılarak yaş, cinsiyet, ek hastalık, iştahsızlık, ghrelin, lökosit, CRP ve vücut kitle indeksi (VKI) gibi parametreler karşıllaştırıldı.

Bulgular: Çalışmaya 30 sağlıklı kişi, 29 nonkomplike apandisit, 29 komplike apandisit olarak 3 grup dahil edildi. Gruplar arasında yaş, cinsiyet, VKİ ve ghrelin düzeyleri arasında anlamlı fark saptanmadı ( $\mathrm{p}>0.05$ ). İştahsızlık, lökosit ve CRP düzeyleri akut apandisitli hastalarda kontrol grubuna göre ileri derecede anlamlı saptandı ( $<<0,001$ ). Hastaların ghrelin değerlerinin lökosit ile korelasyonuna bakıldığında anlamlı bir korelasyon saptanmadı.

Sonuç: Akut apandisit tanısında ve hastalığın ciddiyetinin belirlenmesinde WBC ve CRP gibi serolojik testler kullanılabilir. Akut apandisitin ciddiyet düzeyi arttıkça ghrelin hormon değeri de artmaktadır ancak gruplar arasında anlamlı bir fark saptanmadı. Akut apandisit gibi iştah düzeyinin değiştiği bir hastalık için, daha fazla hasta katılımının olduğu çok merkezli çalışmalara ihtiyaç vardır.

Anahtar Kelimeler: Akut apandisit, c-reaktif protein, lökosit, ghrelin, iştahsılılık

Abstract

Aim: This study aims to investigate the diagnostic value of ghrelin in acute appendicitis and the correlation between ghrelin and routine laboratory tests such as white blood cell (WBC), C-reactive protein (CRP).

Method: We prospectively evaluated patients aged 16-80 years who were operated for acute appendicitis between October 2018 and December 2018. Blood was preoperatively collected for ghrelin, hemogram, and CRP assessments. The patients were divided into 3 groups and evaluated in terms of age, gender, comorbidities, anorexia, ghrelin, leukocyte, CRP, and body mass index (BMI).

Results: The study included 30 healthy individuals, 29 patients with non-complicated appendicitis, and 29 patients with complicated appendicitis. The groups were not statistically different in terms of age, gender, comorbidities, BMI, or ghrelin levels ( $\mathrm{p}>0.05)$. Anorexia and leukocyte and CRP levels were significantly higher in patients with acute appendicitis $(\mathrm{p}<0.001)$. Ghrelin level and leukocyte count were not significantly correlated.

Conclusion: Serological tests such as WBC and CRP can be used in the diagnosis of acute appendicitis and in determining its severity. Ghrelin levels increased with increasing acute appendicitis severity, but this finding was not statistically significant. Further studies with larger samples are needed to better understand how appetite is affected in acute appendicitis.

Keywords: Acute appendicitis, c-reactive protein, leukocyte, ghrelin, loss of appetite

Yazışma Adresi: Rıfat Peksöz, Atatürk Üniversitesi Tıp Fakültesi Genel Cerrahi Anabilim Dalı

E-Posta: rifat-peksoz@hotmail.com

Alınma tarihi: 24.08.2020 / Kabul tarihi: 04.02.2021 / Yayımlanma tarihi: 20.09.2021

Akut apandisit hastalarında ghrelin hormon düzeyi - Peksöz ve ark.

Genel Tip Derg 2021;31(3)252-256 
olarak verildi. Numerik verilerin dağılımına histogram grafikleri ile bakıldı. İkiden fazla grupta numerik veriler One Way ANOVA

Akut apandisit (AA) genel cerrahi kliniklerinde en sık karşılaşılan cerrahi durumdur (1). Tanıda gecikme perforasyon ve akabinde morbiditeyi artırırken diğer taraftan komplikasyonlardan kaçınmak için verilen erken kararlar negatif apendektomiye neden olabilir (2). Çeşitli tanısal araçların kullanımıyla perforasyon oranları, hastanede kalış süresi ve gereksiz cerrahi girişimler azaltılabilir. $\mathrm{Bu}$ testler skorlama sistemleri, ultrasonografi (USG), bilgisayarl tomografi (BT), manyetik rezonans görüntüleme ve laparoskopidir. Tüm bunlara rağmen bilim insanları akut apandisit için daha efektif tanısal prosedürler bulmaya çalışmışlardır. Bu çalışmalar daha çok laboratuvar testleri ve görüntüleme yöntemleri üzerine yoğunlaşmıştır (3). Lökosit ve c-reactive protein (CRP) en çok çalışılan laboratuvar testleridir. Son yıllarda iştah hormonu olarak bilinen ghrelin hormon düzeyi de özellikle enflamatuar hastalıklar için araştırma konusu olmuştur. Akut apandisitte iştahın değiştiği iyi bilinmektedir. Bu sebeple akut apandisit tanısında kullanılabilecek parametrelerden biri de ghrelin hormon düzeyi olabilir.

$\mathrm{Bu}$ çalışmada ghrelin hormonunun akut apandisitin tanısını koymada ve ciddiyetini değerlendirmede tanısal değerine bakılması ve white blood cell (WBC), CRP gibi akut apandisit tanısında kullanılan laboratuvar testleriyle korelasyonuna bakılması amaçlanmıştır.

\section{Materyal ve Metod}

Bu çalışmada Erzurum Atatürk Üniversitesi Tıp Fakültesi Klinik Araştırmalar Etik Kurulu'nun onayı alındıktan sonra 04.10.201820.12.2018 tarihleri arasında karın ağrısı ile acil servise başvuran ve akut apandisit ön tanısı ile genel cerrahi kliniğine yatırılıp ameliyat edilen 16-80 yaş arası hastalar prospektif olarak incelendi. Hastaların anamnez, fizik muayene, laboratuvar, görüntüleme de elde edilen bulgulara göre akut apandisit tanısı konuldu. Preoperatif dönemde hastalardan hemogram ve CRP ile birlikte biyokimya tüpüne ghrelin hormon düzeyi ölçümü için kan alındı. Biokimya tüpüne alınan kan santrifüj edildikten sonra -80 derecede korundu. Dondurulan serum örnekleri çözünmesi için oda sıcaklığında 30 dakika bekletildi ve tüm ölçümler aynı gün yapıldı. Human Ghrelin ELISA Kit Catalog No: E-EL-H1919 96 T isim ve katalog nolu kit Erzurum Atatürk Üniversitesi Tıp Fakültesi Biokimya Laboratuvarında serum örnekleri test prosedürüne uygun olarak çalış1ldı. Kitin düzey algılama aralığı:0,16-10 ng/ml'dir. Hastaların bilgilerine; anamnez bilgilerinden ve Enlil Medikal Bilgi Sistemi veri tabanından ulaşıldı. Çalışmaya 3 grup dahil edildi. Grup I: Sağlık çalışanlarından oluşan 30 sağlıklı kontrol grubu, grup II: Apendiksin histopatolojik durumuna göre nonkomplike apandisit (akut süpüratif apandisit, akut flegmonöz apandisit) 29 hasta, grup III: komplike apandisit (gangrenöz apandisit, perfore apandisit) 29 hasta olarak gruplara ayrıldı. Çalışmaya; çoçuk yaş grubu hastalar, malignite öyküsü olan, immünsüpresyon öyküsü olan, bilinen inflamatuar barsak hastalığı olanlar, gebe hastalar, laboratuvar düzeylerini etkileyebilecek birden fazla ek hastalığı olan hasta ve sağl1klı kişiler, apendiks histopatalojisi normal olan ve ameliyat esnasında apandisit dışında farklı patolojiye sahip hastalar ve 24 saatten daha üzün süre karın ağrısı devam eden hastalar dâhil edilmedi.

\section{İstatistiksel Analiz}

Çalışmanın istatistiği yapılırken tanımlayıcı istatistiklerde numerik veriler ortalama ve standart sapma, kategorik veriler ise sayı ve yüzde ve Kruskal Wallis Testi ile analiz edildi. Ayrica iki numerik verinin durumuna Pearson korelayon analizi ile bakıldı. Kategorik veriler karşılaştırılırken Ki-kare testi kullanıldı. P anlamlılık değeri $<0,05$ olarak kabul edildi. Analizlerde SPSS 23.0 paket programı kullanıldı.

\section{Bulgular}

Çalışmaya 30 sağlıklı kişi, 29 nonkomplike apandisit, 29 komplike apandisit dahil edildi. Hastaların cinsiyet oranlarına bakıldığında grup I (kontrol grubu): E/K 13/17, grup II (nonkomplike apandisit): E/K 15/14, grup III (komplike apandisit): E/K 18/11 olup gruplar arasında anlamlı fark saptanmadı ( $\mathrm{p}>0.05)$. İştahsızlık durumuna bakıldığında grup I: 0 hasta, grup II: 16 hasta, grup III:21 hastada iştahsızlık mevcut olup gruplar arasında anlamlı fark saptand1 $(p<0,001)$. Ek hastalık durumuna bakıldığında ise grup I:4 hasta, grup II:2 hasta, grup III: 6 hastada ek hastalık mevcut olup gruplar arasinda anlaml fark saptanmadı $(\mathrm{p}>0.05)$. Laboratuvar değerlerini etkileyebilecek ek hastalığı olanlar ve birden fazla ek hastalığı olan hastalar çalışma dışı bırakıldı. Hasta gruplarına göre ek hastalık durumu, cinsiyet ve iştahsızlığa bakıldı. İştahsızlık hasta gruplarında sağlıklı kişilere göre anlamlı yüksek bulundu $(\mathrm{p}<0,001)$. (Tablo I)

Tablo I. Ek hastalık durumu, iştahsızlık varlığı ve cinsiyetin hasta gruplarına göre dağılımı

\begin{tabular}{llcccc}
\hline \hline & & \multicolumn{4}{c}{ Apandisit Tipi } \\
\cline { 3 - 6 } & & $\begin{array}{c}\text { Komplike } \\
\text { apandisit } \\
\mathrm{n}(\%)\end{array}$ & $\begin{array}{c}\text { Nonkomplike } \\
\text { apandisit } \\
\mathrm{n}(\%)\end{array}$ & $\begin{array}{c}\text { Sağlıkl } \\
\text { kişiler } \\
\mathrm{n}(\%)\end{array}$ & $\mathrm{p}$ \\
\hline \multirow{2}{*}{ Ek Hastalık } & Var & $6(20,7)$ & $2(6,9)$ & $4(13,3)$ & 0,309 \\
& Yok & $23(79,3)$ & $27(93,1)$ & $26(86,7)$ & \\
\hline \multirow{2}{*}{ Cinsiyet } & Erkek & $18(62,1)$ & $15(51,7)$ & $13(43,3)$ & 0,353 \\
& Kadın & $11(37,9)$ & $14(48,3)$ & $17(56,7)$ & \\
\hline İştahsılık & Var & $21(72,4)$ & $16(55,2)$ & $0(0)$ & $<0,001$ \\
& Yok & $8(27,6)$ & $13(44,8)$ & $30(100)$ & \\
& & & & &
\end{tabular}

Hasta gruplarına göre yaş, ghrelin, CRP, WBC (lökosit) ve vücut kitle indekslerinin (VKİ) ayrıntıları Tablo 2'da görülmektedir. Hastaların yaş ortalaması kontrol grubu kişilerde ise $29,53 \pm 7,18$, nonkomplike grupta $30,41 \pm 11,81$ ve komplike grupta $30,38 \pm 14,50$ olarak hesaplandı. Ghrelin hormon düzeyi değerlerine bakıldığında kontrol grubu kişilerde 2.08, nonkomplike grupta 3.28 ve komplike grupta 3.84 olarak hesaplandı. Lökosit düzeyleri karşılaştırıldığında kontrol grubu kişilerde 8.11 , nonkomplike grupta 13.05 ve komplike grupta $14.71\left(\times 10^{3} / \mu 1\right)$ olarak bulundu. CRP düzeyleri karşılaştırıldığında kontrol grubu kişilerde 0.42 , nonkomplike grupta 3.07 ve komplike grupta 3.61 (mg/l) olarak bulundu. VKİ'ye bakıldığında kontrol grubu kişilerde 23.72 , nonkomplike grupta 23.88 ve komplike grupta 23.97 olarak bulundu. Gruplar karşılaştırıldığında lökosit ve CRP düzeyleri akut apandisitli hastalarda kontrol grubuna göre ileri derecede anlamlı saptand $1(\mathrm{p}<0,001)$. Gruplar arasında ghrelin düzeyi, yaş ve VKİ düzeyleri arasında anlamlı fark saptanmadı $(\mathrm{p}>0.05)$. Hastaların ghrelin değerlerinin lökosit $(\mathrm{r}=0,152 ; \mathrm{p}=0,162)$ ve CRP $(\mathrm{r}=0,117$; $\mathrm{p}=0,284)$ ile korelasyonuna bakıldığında anlamlı bir korelasyon saptanmad1. (Tablo II)

Akut apandisit hastalarında ghrelin hormon düzeyi - Peksöz ve ark. 
Tablo II. Hasta gruplarına göre yaş, ghrelin, lökosit, CRP ve VKİ karşılaştırılması

\begin{tabular}{|c|c|c|c|c|c|c|c|}
\hline & & $\mathrm{n}$ & Ortalama & $\begin{array}{c}\text { Std. } \\
\text { Deviation }\end{array}$ & Minimum & Maksimum & $\mathrm{p}$ \\
\hline \multirow{3}{*}{ Yaş } & $\begin{array}{r}\text { Komplike } \\
\text { apandisit }\end{array}$ & 29 & 30,38 & 14,50 & 16 & 70 & $0,686 * *$ \\
\hline & $\begin{array}{c}\text { Nonkomplike } \\
\text { apandisit }\end{array}$ & 29 & 30,41 & 11,81 & 15 & 61 & \\
\hline & Sağlıklı kişiler & 30 & 29,53 & 7,18 & 22 & 51 & \\
\hline \multirow{3}{*}{$\begin{array}{c}\text { Ghrelin } \\
\text { (ng/ } \\
\mathrm{ml})\end{array}$} & $\begin{array}{r}\text { Komplike } \\
\text { apandisit }\end{array}$ & 29 & 3,84 & 4,15 & 0,16 & 10,00 & $0,139 * *$ \\
\hline & $\begin{array}{c}\text { Nonkomplike } \\
\text { apandisit }\end{array}$ & 29 & 3,28 & 4,33 & 0,16 & 10,00 & \\
\hline & Sağlıklı kişiler & 30 & 2,08 & 3,23 & 0,13 & 10,00 & \\
\hline \multirow{3}{*}{$\begin{array}{c}\text { Lökosit } \\
\left(\times 10^{3 /}\right. \\
\mu \mathrm{l})\end{array}$} & $\begin{array}{r}\text { Komplike } \\
\text { apandisit }\end{array}$ & 27 & 14,71 & 4,18 & 8,03 & 26,09 & $<0,001^{*}$ \\
\hline & $\begin{array}{c}\text { Nonkomplike } \\
\text { apandisit }\end{array}$ & 29 & 13,05 & 4,87 & 3,96 & 24,67 & \\
\hline & Sağlıklı kişiler & 30 & 8,11 & 1,92 & 5,26 & 13,50 & \\
\hline \multirow{3}{*}{$\begin{array}{c}\text { CRP } \\
\text { (mg/ } \\
\text { dl) }\end{array}$} & $\begin{array}{r}\text { Komplike } \\
\text { apandisit }\end{array}$ & 29 & 3,61 & 4,66 & 0,32 & 20,90 & $<0,001 * *$ \\
\hline & $\begin{array}{c}\text { Nonkomplike } \\
\text { apandisit }\end{array}$ & 28 & 3,07 & 3,68 & 0,33 & 13,20 & \\
\hline & Sağlıklı kişiler & 29 & 0,42 & 0,29 & 0,30 & 1,37 & \\
\hline \multirow{3}{*}{ VKİ } & $\begin{array}{r}\text { Komplike } \\
\text { apandisit }\end{array}$ & 29 & 23,97 & 4,69 & 14,69 & 32,66 & $0,972^{*}$ \\
\hline & $\begin{array}{c}\text { Nonkomplike } \\
\text { apandisit }\end{array}$ & 29 & 23,88 & 3,99 & 15,92 & 31,08 & \\
\hline & Sağlıklı kişiler & 30 & 23,72 & 3,83 & 17,97 & 33,51 & \\
\hline
\end{tabular}

*One Way ANOVA uygulanmıştır. **Kruskal Wallis Testi uygulanmıştır.

\section{Tartışma}

Akut apandisit hayat boyu görülme insidansı $\% 7$ olup en fazla genç insanlarda görülen cerrahi acildir $(4,5)$. Apandisit en fazla 20-40 yaş arasında görülmekte olup ortalama görülme yaşı 31 yaştır ve erkeklerde yaklaşık 1.4 kat daha fazla görülmektedir $(6,7)$. Bizim çalışmamızda da literatüre benzer şekilde akut apandisit erkeklerde 1.3 kat daha fazla görülmüş olup hastaların ortalama yaşı 30 olarak bulunmuştur.

Akut apandisit tanısının konulması temelde anamnez ve fizik muayeneye dayanır. Hizlı tanı perforasyon ve komplikasyonları önleyebilir. Tüm vakaların tanısını tam olarak doğrulayacak tek bir semptom, bulgu, ya da test yoktur. Ancak akut apandisitten şüphelenilen hastalarda artmış CRP ölçümleriyle beraber artmış WBC ve nötrofil düzeyinin kombine edilmesi \%95 doğru tanı koydurur (8). Böylece akut apandisit tanısında en sık kullanılan ve birçok sağlık kuruluşunda kolay ulaşılabilen serolojik göstergeler; lökosit sayısı ve C-reaktif protein (CRP) 'dir $(9,10)$. WBC (lökosit) yüksekliği akut apandisit hastaları için birçok çalışmada detaylı olarak incelenmiştir. Lökosit düzeyi akut apandisit hastalarında genellikle yükselmesine rağmen birçok enflamatuar hastalığında da yükseldiği için spesifik bir marker değildir (11).

Yapılan çalışmalarda WBC düzeyi kontrol grubunda 7.6-11.9, nonkomplike apandisit hastalarında 11.75-13.8, komplike

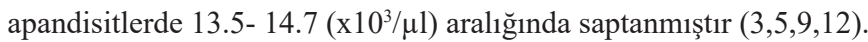

Akut apandisit hastalarında ghrelin hormon düzeyi - Peksöz ve ark.
Bizim çalışmamızda kontrol grubunda ortalama WBC düzeyi 8.1, nonkomplike apandisit hastalarında 13.05, komplike apandisitlerde $14.71\left(\mathrm{x} 10^{3} / \mu \mathrm{l}\right)$ olarak saptanmış olup gruplar arasında anlamlı fark saptanmıştır $(\mathrm{p}<0.001)$. Bu sonuçlara göre lökosit değeri arttıkça akut apandisit olma olasılığı artmaktadır ve daha yüksek değerlerde olayın komplike olma riski daha fazla gözükmektedir. Böylece WBC değerleri akut apandisitin ciddiyetini belirlemede önemli rol oynamaktadır.

Akut apandisit tanısında en çok çalışılan parametrelerden bir diğeri de CRP'dir. Yapılan çalışmalarda CRP düzeyi nonkomplike apandisit hastalarında 2.4-5.3, komplike apandisitlerde 3.2-12.4 (mg/dl) aralığında saptanmıştır $(9,12,13)$.

Bizim çalışmamızda kontrol grubunda ortalama CRP düzeyi 0.42 , nonkomplike apandisit hastalarında 3.07, komplike apandisitlerde $3.61(\mathrm{mg} / \mathrm{dl})$ olarak saptanmış olup gruplar arasında anlamlı fark saptanmıştır $(p<0.001)$. Bulgularımız literatürle uyumludur. Akut apandisit hastalarında CRP düzeyi ne kadar yüksek ise apendiksin komplike hale gelme riski o kadar yüksektir denilebilir.

Gastrointestinal semptomlar akut apandisitte s1k görülür ancak sensitivite ve spesifiteleri düşüktür. Abdominal ağrı ve iştahsılılık neredeyse hastaların tamamında bulunur (14). İştahsızlık apandisitin ilk ve en değişmez semptomudur. Eğer iştahsızlık yok ise akut apandisit tanısı için tekrar düşünülmelidir. Semptomların ortaya çıkma sırasıda ay1rıcı tanıda önemlidir. Akut apandisit hastalarının \%95'inde ilk semptom iştahsızlık olup bunu karın ağrısı ve bulantı, kusma takip eder (15). Vücutta iştah düzenleyici olarak çeşitli hormonlar bilinmektedir. Ghrelin en iyi bilinen iştah uyarıcı hormondur (16). Ghrelin; esas salınım yeri mide oksintik mukozasındaki A- benzeri hücrelerden olup büyüme hormonu salınımını uyaran, 28 aminoasitli, peptid yapıda bir hormondur (17). Çalışmalarda ghrelinin antienflamatuar aktivitelerde rol aldığı gösterilmiştir (18). Bu hormon T hücrelerinden salgılanmaktadır. Ghrelin GHS-R aracılığıyla IL-1 beta, IL-6 ve TNF-alfa gibi anorektik stokinlerin exprosyonunu azaltmakta ve antienflamatuar etkisini bu şekilde göstermektedir (19).

Ghrelin hormonu inflamasyonun şiddetiyle orantılı olarak artar ve hastalıklarının seyrini belirlemede kullanışlı bir parametredir (20). Ghrelin hormon düzeyi obezite veya anoreksik durumlardan etkilenmektedir (21). Bu yüzden çalışmamızda VKİ eşit gruplar oluşturulmaya çalışılmıştır.

Ghrelin hormonun akut apandisit hastalarında ilk defa Çetinkaya ve ark. tarafından çalışılmıştır. Bu çalışmada gruplar akut apandisit $(n=20)$, kolelitiazis $(n=10)$ ve kontrol grubu $(n=16)$ hastadan oluşmuştur. Akut apandisit hastalarında diğer gruplara göre daha düşük saptanmıştır. Yine aynı çalışmada ameliyat öncesi hormon düzeyi değerleri ameliyat sonrasına göre daha düşük düzeyde saptanmıştır. Hormon düzeyinin azalmasının akut apandisitte iştahın azalmasına bağlanmıştır (22). Bu çalışmada çalışılan grupların farklı hastalıklar olması, bu hormonun akut apandistin ciddiyet derecindeki değişimini ölçmeye yaramayacaktır.

Kanat ve arkadaşları akut pankreatitin tanısı ve şiddetini değerlendirmek için yapılan çalışmada; 22 hasta hafif pankreatit, 8 hasta şiddetli pankreatit olarak değerlendirilmiş. İki grup arasında açillenmiş ve de-açillenmiş ghrelin değerleri açısından hastaneye ilk başvuru sırasında ve oral beslenmenin başlatılmasından sonra istatistiksel bir farklılık ortaya koymamıştır. Pankreatik inflamasyon 
sırasında sürekli olarak yüksek serum ghrelin değerleri, ghrelinin, hastalığın seyrinin izlenmesinde yardımcı bir parametre olarak kullanılabileceğini düşündürmektedir. Bununla birlikte, ghrelin hormonu ve akut pankreatitin şiddeti arasında bir ilişki kurulamamıştır (20).

Kerem ve arkadaşlarının akut pankreatitin ciddiyetini belirmede 90 sıçanda yaptığı deneysel çalışmada akut pankreatitin başlamaşından sonra ghrelin seviyeleri artarak 24 saat içerisinde maksimum seviyesine ulaştığ 1 gösterilmiştir. Akut nekrotizan pankreaitte ödematöz pankreatite göre anlamlı olarak daha yüksek saptanmıştır (23).

Dayanan'ın Behçet hastaları üzerinde yaptığı çalışmada ghrelin düzeyleri aktif hasta grubunda daha yüksek saptanmıştır (24).

Fakat ghrelin hormon düzeyinin hastalığın ciddiyeti ile ters orantılı olduğunu gösteren çalışmalarda vardır. Yapılan bazı çalışmalarda ghrelin hormon düzeyleri akut pankreatit hastalarında sağlıklı kontrol grubuna göre anlamlı olarak daha düşük bulunmuştur $(25,26)$.

Eren'in yaptığı bir çalışmada yaş, cinsiyet dağılımı, VKİ benzer olan 40 Juvenil İdiyopatik Artritli (JIA) hasta ve 32 sağlklı çocuk karşılaştırılmış. JIA'lı hastaların ghrelin düzeyi 0.47 , kontrol grubu hastalarının ghrelin düzeyi $0.5(\mathrm{ng} / \mathrm{ml})$ olarak bulunmuş ve iki grup arasında ghrelin değerlerinde istatistiksel olarak anlamlı fark bulunmamıştır (27).

Literatüre bakıldığında çalışmamız şu ana kadar akut apandisit hastalarının gruplara ayrılarak WBC ve CRP değerleriyle birlikte ghrelin hormonunun çalışıldığıilk çalışma olma özelliğini taşımaktadır. Ghrelinin yaş, pubertal durum, VKİ, birden fazla kronik hastalıklar gibi birçok etkenden etkilenebileceği bilgisi doğrultusunda, grupların bu etkenlerden en az etkileneceği düzeyde olgular karşılaştırıldı.

Çalışmamızda ghrelin düzeyi enflamasyonun şiddetiyle korele olarak komplike apandisit hastalarında, nonkomplike apandisit hastalarına göre daha yüksek bulundu. Aynı zamanda nonkomplike apandisit hastalarının ghrelin düzeyleride sağlıklı gönüllü kişilerden yüksek saptand, fakat istatiksel olarak anlamlı bir fark saptanmadı. Ghrelin hormon düzeyinin nasıl etkilendiği ile ilgili literatürde karşıt sonuçlar ortaya konmuş olup olayın fizyolojisi henüz netlik kazanmamıştır. Hastalık halinde iştahsızlık oluştuğu için, ghrelin hormon düzeyinin iştahı artırmaya yönelik olarak arttığını düşünmekteyiz.

\section{Çalışmanın kısıtlılıkları}

Hasta sayısının az olması ve kontrol grubunun negatif apendektomi hasta grubundan seçilmemesi çalışmamızın kısıtlılıklarıdır. Ghrelin'i etkileyen veya antagonize eden insülin, büyüme hormonu, leptin, nöropeptid YY gibi hormonlar aynı anda ölçüldüğünde, akut apandisit vakalarında ghrelin'in önemi daha açık olacaktır.

\section{Sonuç}

Akut apandisit tansında ve hastalığın ciddiyetinin belirlenmesinde WBC ve CRP gibi serolojik testler kullanılabilir. Literatürde ghrelin hormon düzeyi ile enflamatuar hastalıklar arasında her ne kadar bağlantı kurulsa da şu anki bilgiler doğrultusunda hastalıkta hormon düzeyi artmakta $\mathrm{m} 1$ ya da azalmakta mı noktasında henüz bir konsensus oluşturulamamıştır. Çalışmamızda akut apandisitin ciddiyeti arttıkça ghrelin hormon düzeyi daha da artmaktadır ancak gruplar arasında anlamlı bir fark saptanmamıştır. Akut apandisit gibi iştah düzeyinin hastaların çoğunda değişen bir hastalık için, hastalarının gruplara ayrılarak daha fazla hasta katılımının olduğu çok merkezli çalışmalara ihtiyaç vardır.

\section{Kaynaklar}

1. Brunicardi FC, Andersen DK, Billiar TR. Schwartz's Principles of Surgery. 9th edition, 2010 .

2. Eryılmaz R, Şahin M, Alimoğlu O, Baş G, Özkan OV. Negatif apendektomileri Önlemede c-reaktif protein lökosit sayımının değeri. Ulus Travma Acil Cerrahi Derg 2011;7:142-145.

3. Akgül N, Gündeş E. Neutrophil/lymphocyte ratio in acute appendicitis: A state hospital experience. Turk J Colorectal Dis. 2016;26(4):121-4.

4. Yokoyama S, Takifuji K, Hotta T, et al. C-Reactive protein is an independent surgical indication marker for appendicitis: a retrospective study. World J Emerg Surg 2009;4:36.

5. Eren T, Tombalak E, Burcu B, et al. Akut apandisit olgularında nötrofil/lenfosit oranının tanıda ve hastalığın șiddetini belirlemedeki prediktif değeri. Dicle Tıp Dergisi. 2016;43(2):279-84

6. Akyüz M, Topal U, Gök M, et al. Predictive value of neutrophil/lymphocyte ratios in the diagnosis of acute appendicitis. Med J Bakirkoy 2020;16(1):76-84

7. Jaffe BM, Berger DH. The Appendix. In: Schwartz's. Principles of surgery 8nd ed 2008;29:1162

8. Groselj-Grenc, M., Repse, S., Dolenc-Strazar, Z., Hojker, S., \& Derganc, M. Interleukin-6 and lipopolysaccharide-binding protein in acute appendicitis in children. Scandinavian Journal of Clinical and Laboratory Investigation. 2007;67, 197-206.

9. Güler K, Tihan D, Duman U, ve ark. Akut Apandisit Hastalarında Ameliyat Öncesi Serum C-Reaktif Protein ve Lökosit Değerleri Perforasyon Varlığının Ön Görülebilmesinde Etkili Midir?.KRHD,2016;26-:6-12.

10. Lurie S, Rahamim E, Piper I, Golan A, Sadan O. Total and differential leukocyte count percentiles in normal pregnancy. Eur J Obstet Gynecol Reprod Biol. 2008;136(1):16-19.

11. Shogilev DJ, Duus N, Odom SR, Shapiro NI. Diagnosing Appendicitis: Evidence-Based Review of the Diagnostic Approach in 2014. West J Emerg Med 2014;15:859-871.

12. Ayrık C, Karaaslan U, Dağ A, ve ark. Lökosit sayısı, yüzde nötrofil oranı ve Creaktif protein konsantrasyonlarının "kesim değeri" düzeylerinde apandisit tanısındaki değerleri. Ulus Travma Acil Cerrahi Derg 2016;22(1):76-83.

13. Yang HR, Wang YC, Chung PK, et al. Laboratory tests in patients with acute appendicitis. ANZ J Surg 2006;76:71-4.

14. Brunicardi FC, Andersen DK, Billiar TR, et al, editors. Schwartz's Principles of Surgery. 10 ed. New York: McGraw-Hill Education; 2014; p. 1241-62.

15. Sandberg AA, Bahadır MG. Apandisit Üzerine Tarihi Notlar- Akut Apandisitin Ayırıcı Tanısı ve Semptomlar. Akut Apandisitte Tanı Tedavi ve Kanıta Dayalı Cerrahisi. I. Baskı. Avrupa Kitapçılık. İstanbul, 2008;35-65.

16. Sağkan Öztürk A, Arpacı A . Obezite ve Ghrelin/Leptin İlişkisi. Mustafa Kemal Üniversitesi Tip Dergisi. 2018; 151-136.

17. Kojima M, Hosoda H,Date Y: Ghrelin is a growth-hormone-releasing acylatedpeptide from stomach. Nature, 1999;402:656- 660.

18. Polińska B, Matowicka-Karna J, Kemona H. The role of ghrelin in the organism. Postepy Hig Med Dosw (Online) 2011; 65: 1-7.

19. Dixit VD, Schaffer EM, Pyle RS, et al. Ghrelin inhibits leptin- and activation-induced proinflammatory cytokine expression by human monocytes and T cells. J Clin Invest 1 2004;114: 57-66.

20. Kanat BH, Ayten R, Aydin S, et al. Significance of appetite hormone ghrelin and obestatin levels in the assessment of the severity of acute pancreatitis. Turkish J Gastroenterol.2014;25: 309-313. 
21. Soriano-Guillén L, Barrios V, Campos-Barros A, Argente J. Ghrelin levels in obesity and anorexia nervosa: effect of weight reduction or recuperation. J Pediatr 2004;144(1):36-42.

22. Cetinkaya Z, Aydin S, Cerrahoglu YZ, et al. Changes in appetite hormone (ghrelin) levels of saliva and serum in acute appendicitis cases before and after operation. Appetite. 2009;52:104-7

23. Kerem M, Bedirli A, Pasaoglu H, et al. Role of ghrelin and leptin in predicting the severity of acute pancreatitis. Dig Dis Sci 2007; 52: 950-5.

24. Dayanan R. Behçet Hastalığında Serum Ghrelin ve Obestatin Düzeyleri, Ghrelin ve Ghrelin Reseptörü Gen Polimorfizmleri. Yayımlanmış Uzmanlık Tezi. Fırat Üniversitesi Tıp Fakültesi, Elazığ, 2011

25. Panek J, Bonior J, Pieton J, Jaworek J. Serum leptin and ghrelin levels in patients in the early stages of acute biliary pancreatitis and different degrees of severity. Pol PrzeglChir. 2014;86(5):211-7.

26. Wang L, Huang X-E, Ji Z-Q et al. Safety and Efficacy of a Mouth-Rinse with Granulocyte Colony Stimulating Factor in Patients with Chemotherapy-Induced Oral Mucositis. Asian Pac. J. Cancer Prev. 2016;17, 413-418.

27. Eren S. Juvenil idiyopatik artritli hastalarda serum ghrelin, leptin, rezistin ve adi ponektin düzeylerinin nutrisyonel durum ve inflamatuvar belirteçlerle ilișkisi. Uzmanlık Tezi. Dokuz Eylül Üniversitesi Tıp Fakültesi, İzmir, 2011. 